\title{
Empowerment of Single Mothers Livelihood through Comprehensive Social Support System
}

Nur Najwa Hanani Abd. Rahman, Nasiibah Ramli, Muhammad Naqib Hamdan

To Link this Article: http://dx.doi.org/10.6007/IJARBSS/v12-i1/11602 DOI:10.6007/IJARBSS/v12-i1/11602

Received: 20 November 2021, Revised: 23 December 2021, Accepted: 30 December 2021

Published Online: 08 January 2022

In-Text Citation: (Rahman et al., 2022)

To Cite this Article: Rahman, N. N. H. A., Ramli, N., \& Hamdan, M. N. (2022). Empowerment of Single Mothers Livelihood through Comprehensive Social Support System. International Journal of Academic Research in Business and Social Sciences, 12(1), 155-162.

Copyright: (C) 2022 The Author(s)

Published by Human Resource Management Academic Research Society (www.hrmars.com) This article is published under the Creative Commons Attribution (CC BY 4.0) license. Anyone may reproduce, distribute, translate and create derivative works of this article (for both commercial and non0-commercial purposes), subject to full attribution to the original publication and authors. The full terms of this license may be seen at: http://creativecommons.org/licences/by/4.0/legalcode

Vol. 12, No. 1, 2022, Pg. 155 - 162

Full Terms \& Conditions of access and use can be found at http://hrmars.com/index.php/pages/detail/publication-ethics 


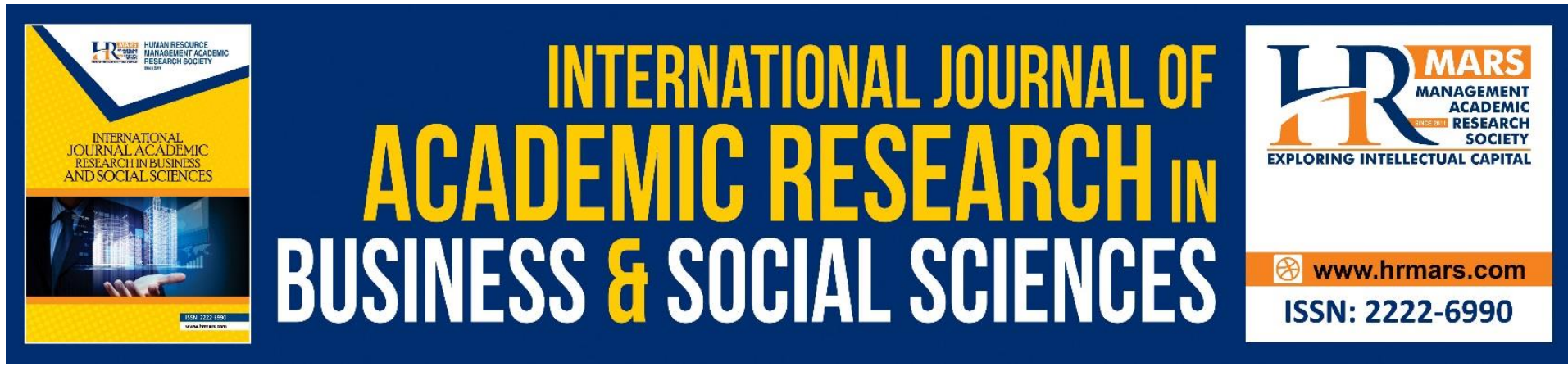

\title{
Empowerment of Single Mothers Livelihood through Comprehensive Social Support System
}

\author{
Nur Najwa Hanani Abd. Rahman, Nasiibah Ramli, Muhammad \\ Naqib Hamdan \\ Akademy of Islamic Civilisation, Faculty of Social Sciences and Humanities, Universiti \\ Teknologi Malaysia, 81310 Johor Bahru, Johor, Malaysia. \\ Email: nasiibah@utm.my,mohammadnaqib@utm.my \\ Corresponding author: nurnajwahanani@utm.my
}

\begin{abstract}
Divorced, separated, and widowed women are heavy-laden with various commitments and responsibilities either from the financial, social or emotional aspects. Excessive obligations can have a negative impact on a person's well-being, as well as the well-being of their children and dependents. Thus, support from a variety of sources is required to help single mothers overcome their difficulties. The purpose of this study is to identify government and nongovernment organisations that have implemented social support programmes for single moms. Additionally, this study will assess the economic, skill, and psychological needs of single mothers in order to facilitate the provision of improved social support programmes in the future. Literature review and content analysis are used inductively and deductively to obtain thorough and complete analysis on this issue. The study found that social support from the aspects of family and society, financial and welfare as well as moral support are essential aspects for single mothers in moving forward new life with their children. Implementation of Islamic social support system through enforcement of wali concept is proposed as the initial steps to be taken in ensuring single mothers' welfare at micro level and government support through various aids and facilities for the single mothers at the macro level.
\end{abstract}

Keywords: Single Mother, Social Support System, Islamic Support System, Women Empowerment

\section{Introduction}

Family institution is a key social organisation that consists of a social unit formed by blood ties, marriage, or adoption. Mother and father are two significant players in a family institution who play an essential role in the growth and well-being of their children and dependents. However, some families are put to the test when a partner dies or divorces, leaving a single parent to raise their children alone. This article focused on the issues faced by single moms, as women in many traditional contexts were not the breadwinners of the family, posing numerous challenges to single mothers, including financial, household management, child education, replacing the role of father and so on. 
Single mothers are women who are single without a husband due to divorce, death of a husband, or who have children outside of marriage relationships, whether adopted or illegitimate children, and are responsible for providing for themselves, their household, and the children under their care (United Nation Development Program, 2007; Ministry of Women, Family and Community Development/KPWKM, 2015). A single mother, in other terms, is a woman who maintains and manages her family without the assistance of a husband.

Previous researches have observed various solitary challenges faced by single mothers such as economic challenges (Melody \& Daniel, 2020; Marziah et al., 2019; Widan \& Greef, 2019), psychological and emotional challenges (Lee, 2021; Xiaoman \& Iccha, 2018), challenges of educating children (Lee, 2021; Xiaoman \& Iccha, 2018) and so on. Recognizing the responsibility and role borne by single mothers, social support from various parties, especially family, relatives, and neighbors, are needed to ensure single mothers' mental, physical, spiritual, and emotional well-being are looked after. Therefore, this study highlights the social support needed by single mothers in reducing the burdens and stresses of life.

\section{Single-mother Challenges}

Taking on a dual role as a single mother is a difficult task that has raised the risk of depression and the poverty gap in society. Furthermore, single mothers must adapt to new scenarios in their lives when confronted with serious challenges (Marziah et al., 2019). Single mothers, in other words, must adjust to new routines, obligations, and lives.

In line with that, new challenges will also emerge in the lives of single mothers. The following are some of the difficulties that single mothers face:

\section{i. Economic Challenges}

For single mothers, economic stability, particularly from a financial standpoint, is a huge difficulty. This has been an issue of debate that has been brought up in almost every study on single mothers (Melody \& Daniel, 2020; Marziah et al., 2019). The justification is that single mothers, in addition to providing adequate education to their children, need to find a source of income to support the high cost of living and everyday costs, especially in urban regions.

Seeking job placement is also a challenging task, especially when the single mother is a full-fledged housewife from the very beginning. This is because the reality of employment now looks for experience in addition to individual qualifications (Zafir \& Fazilah, 2007). In addition, single mothers will also have to balance their working life with the childcare and safety of the children during working hours. Sending children to childcare and nursing centers also requires substantial expenditure (Marziah et al., 2019).

Furthermore, most single mothers prefer to be self-employed and involved in business venture to gain the freedom of childcare time. Accordingly, the majority of single mothers especially those on low incomes are burdened with various dependents such as house rent, daily food, clothing and other necessities (Melody \& Daniel, 2020). Thus, this situation causes economic problems to be the biggest challenge for single mothers in continuing life.

\section{ii. Social Challenges}

The focus of social problems is on the general public's perception of single mothers. This is because human life is inextricably linked to social ties with others in the society. To some extent, this attachment has negative consequences for single mothers. This is owing to 
the fact that single mothers, particularly widowed mothers, face a cultural stigma (Marziah et al., 2018; Marziah et al., 2019; Ida Rahayu et al., 2019; Lee, 2021).

This stigma and perception become a nightmare for single mothers to move freely during the adjustment phase in order to move on to a new life. Negative societal beliefs can also put this group under a lot of mental and emotional strain (Marziah et al., 2018; Marziah et al., 2019). Because of society's negative attitude toward single mothers, they become secluded and prefer to be alone.

Accordingly, stigma and negative societal perspectives add to the burden of single mothers indirectly. Worse, if these problems are not addressed and appropriately adapted, the condition can lead to emotional and mental abuse.

\section{iii. Psychological and Emotional Challenges}

In addition, the problems of being a single mother from a psychological and emotional standpoint are often highlighted in the discussion. When faced with life challenges as well as unexpected undesired occurrences, a person's emotions are frequently disrupted (Marziah et al., 2019). In the context of single mothers, the death of a husband or the occurrence of a divorce has a strong emotional impact, especially in the early stages of the catastrophe. Single mothers must come to terms with the loss of a partner and deal with challenges on their own. Single mothers' emotional disturbance is exacerbated by pressures from relatives, in-laws, children's arrogance, and unpleasant words from neighbours.

Single mothers' emotional problems have an impact not only on themselves, but also on others in the community, particularly children who share a home (Marziah et al., 2019). Children become a safe haven for single mothers to vent their frustrations, become victims of abuse, and not receive the affection they deserve, among other things. The treatment of single mothers has an impact on the impact, feelings, and psychology of children.

\section{iv. Childrens' Education and Upbringing Challenges}

Furthermore, because children are a gift from Allah SWT, they must be well-trained and taught. Majority of parents find it difficult to educate their children. When only one side bears accountability, this becomes more difficult. Parents are the primary influencers in their children's personal development as the Prophet SAW said:

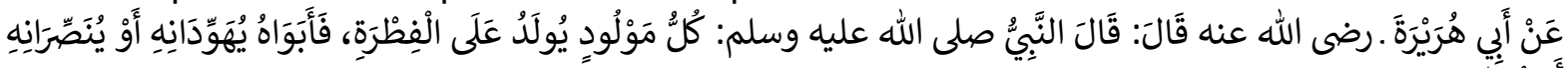

$$
\begin{aligned}
& \text { أَوْ يُمَنِجَِِسَانِهِ }
\end{aligned}
$$

Meaning: Every child that is born in a state of fitrah (pure), it is both parents who make him a Jew or a Christian or a Magian. (HR Bukhari no. 1385)

Dealing with varied children's frustrations is a major problem for parents, particularly single mothers. This is due to the fact that single moms must work to support their families, care for their homes, control their emotions, and care for and educate their children.

Children of all ages, whether newborns, children, or teenagers, have a variety of educational methods and approaches. For single mothers, behavioural issues, a lack of supervision and attention, as well as ways to socialise with peers, become important topics in their children's education (Gulfem, 2010; Marziah et al., 2019). Because there is no father figure to provide as a role model for the children, they may have personal issues in the future.

As a result, single mothers who are exclusively responsible for their children's upbringing must persevere and seek help, particularly social assistance. The significant stress that a single mother is experiencing is likely to have an impact on her physical and mental 
health. In short, a lack of social support in many ways will lead to internal tensions that will have a severe influence on single mothers and their children's well-being.

\section{Scope and Methodology}

This research is presented to highlight the need of social support for single mothers dealing with life's challenges. This is a qualitative study in which the data collecting approach is a literature review. To complement and complete the data, reference materials from articles, journals, books, seminar papers, and other sources are employed.

The data was then evaluated utilising inductive, deductive, content analysis, and thematic methodologies to come up with the study's findings. The study's scope was limited to an examination of social assistance for single mothers.

\section{Comprehensive Support System for Single-Mother}

Single mothers need inner fortitude to deal with the challenges and stresses of life. When confronted with negative impressions and scorn from society, a strong spirit and tenacity must be ingrained in the soul. The obstacles and problems faced by single mothers, on the other hand, are garnering increased attention in society. The argument is that a number of people stepped up to offer help and support.

To some extent, this exposure can awaken the minds of many people, elicit a positive response from numerous parties, and alleviate the burden encountered by single mothers. In this sense, single moms are offered many sorts of assistance and support, whether from the government, the private sector, or the private sector, in order to lessen the burden they bear. Among the types of social assistance required are:

\section{i. Family Institution Support System}

The family is a vital part of one's existence, and it plays a vital role in providing support to its members. According to Abdul Manaf and Norliza (2016), the family occupies a central, essential, and primary role in society. A combination of family institutes contributes to the formation of society. A harmonious and flourishing society will be born from family institutes that support one another.

Families can assist single mothers in a variety of ways, not only financially, as discussed in this article. Non-monetary assistance, such as childcare while single mothers are at work, competent counselling, and emotional support from relatives, is more important than cash assistance (Crosier et al., 2007; Marziah et al., 2019). This is because single mothers' emotional bewilderment is at an all-time high during the process of adjusting to a new existence.

Single mothers labour tirelessly to get through each day without ignoring their responsibilities to their children. They are exhausted not just physically, but also intellectually and emotionally. Single mothers benefit enormously from the support of a responsible and resolute family in overcoming the obstacles that lie ahead.

Besides that, empowerment of wali concept according to Islamic social structure can provide a way out for single mothers in the face of live challenges. It is the responsibility of wali for the single mother or the children under her care to ensure that their lives are well looked after. In the event that there is no wali or that the wali is incapable to provide help, then Baitul mal can step in to provide support and help for them. This is supported by Quranic verse in Surah An-Nisa' verse 34 which means: 
"Men are in charge of women by [right of] what Allah has given one over the other and what they spend [for maintenance] from their wealth."

Thus, wali is a trust entrusted to men in general to take care and ensure that the affairs of those in his care are always in excellent hands and are never put in jeopardy, especially in situations of marriage, alimony, adoption, and other similar matters.

\section{ii. Society Support}

In addition, social support from the community especially individuals close to single mothers can reduce the burden of single mothers. This is because the stigma and bad views towards single mothers cause them to be ridiculed and marginalized by society especially neighbors and park residents (Xiaoman \& Iccha, 2018; Ida Rahayu et al., 2019).

Negative perceptions of single mothers need to be changed so that they have the freedom to continue living and the strength to face trials without negative views from society. If this stigma is not corrected, society's action against single mothers is just like sprinkling salt on wounds.

In this case, the community needs to work together to provide encouragement, motivation, care, provide assistance directly or indirectly so that the pressures and challenges of life can be overcome well by single mothers.

\section{iii. Economic and Welfare Support}

Furthermore, financial and welfare assistance, such as supplying basic requirements for the family, can be a huge help to single mothers (Xiaoman \& Iccha, 2018). This is because the most difficult component of continuing to live and raise children is the financial aspect.

From a Malaysian standpoint, there are a number of parties, both government and private, who are willing to help alleviate this financial strain. Amanah Ikhtiar Malaysia (AIM), Majlis Amanah Rakyat (MARA), and the Department of Agriculture are just a few examples. These organisations have assisted many low-income single mothers and people from lowincome families in obtaining loans for basic business capital (Human Rights Commission of Malaysia/SUHAKAM, 2012).

Thus, single mothers do not have to confront financial challenges alone, and they may satisfy the demands of their families while gaining the strength to continue living, thanks to financial aid from a variety of sources.

\section{Moral Support}

Social support also includes provision of knowledge, training, skills, problem sharing as well as exchanging opinions and advice (Marziah et al., 2018). This moral support becomes the starting point for single mothers to accept the test and independently continue life without the presence of a husband.

The provision of knowledge, training and skills such as cooking, sewing, knitting, computer skills and so on can be utilized by single mothers to generate income through business. Now, various online businesses can be implemented to expand the target customers. With this facility, monitoring and care of children can also be guaranteed.

There are many bodies and associations that provide such social assistance such as assistance from the Mykasih Foundation, Women Development Department, single mothers associations and other community service centers (SUHAKAM, 2012). The available platforms should be leveraged and promoted in order to provide convenience to single mothers while also indirectly assisting them in reducing their load. 
As a result, assisting single mothers is not solely the obligation of the family or certain parties, but it is also a communal responsibility that must be shared, particularly among Muslims. This coincides with the hadith of the Prophet SAW:

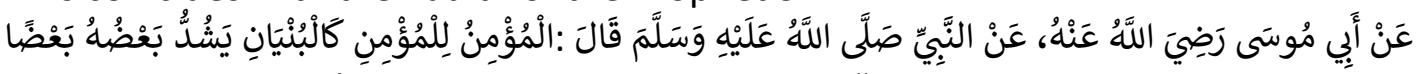
From Abu Musa radhiyallahu' anhu, the Prophet SAW said: "A believer with another believer is like a building that strengthens each other". (HR Bukhari no. 6026 and Muslim no. 2585)

\section{Conclusion}

In conclusion, the researchers discovered that there are numerous economic support programmes for single mothers that are channelled through monthly or annual allowances as well as business aid. However, social support is perceived to be less psychologically beneficial than other types of support. Additionally, researchers recommended that single mother daycare centres be expanded in each state to allow single mothers to work without worrying about the care of children left behind while they work. This study also found that social support can help single mothers cope with the obstacles and pressures that they experience. Single mothers might benefit from social assistance to reach a balanced well-being in terms of physical, spiritual, emotional, and intellectual well-being. Support from family and community members, financial and welfare support, and psychological support are all components of social support that single mothers require to help them cope with problems and obstacles.

In line with that, social support among single mothers plays an important role in easing their burden. As a result, attempts to give social assistance to single moms necessitate the participation of all parties involved, particularly those closest to them. This effort must be made consistently and conscientiously in order to sustain harmony and well-being.

\section{Acknowledgement}

This work was supported by Minister of Education Malaysia (FRGS/1/2019/SSI03/UTM/02/4).

\section{References}

Abdul Razak, A. M., \& Mokhtar, N. (2016). "Isu-isu sokongan sosial dalam kalangan kanakkanak mangsa penderaan seksual di institusi pemeliharaan dan perlindungan". Journal of Techno Social, 8(2).

Al-Bukhari. (2002), Sahih Al- Bukhari, t.tp.: Dar Tuq al-Najah al-Naisaburi, M. (t.t), Sahih Muslim, Kitab al-Salam, Beirut: Dar Ihya' Al-Turath Al-'Arabi.

Cakir, S. G. (2010). A pilot study on stress and support sources of single mothers in Turkey. Procedia Social and Behavioral Sciences 5, 1079-1083.

Crosier, T., Butterworth, P., \& Rodgers, B. (2007). Mental health problems among single and partnered mothers. The role of financial hardship and social support. Soc Psychiatry Epidomial, 42, 6-13.

KPWKM, (Ministry of Women, Family and Community Development). (2015). Pelan Tindakan Pemerkasaan Ibu Tunggal 2015-2020. Putrajaya.

Lee, J. H. (2021). Effectiveness of group art therapy for mothers of children with disabilities. The Arts in Psychotherapy 73, 1-8.

Mahat, I. R., Mahat, N., Mustafa, A. M. S., Ismail, W. M. (2019). Empowering Single Mothers Through Implementation and Recognition of Law in Malaysia. International Journal for Studies on Children, Women, Elderly and Disabled, Vol. 7 (June), 53-59. 
Makhbul, Z. M., \& Hasun, F. M. (2007). Amalan Pengambilan Dan Pemilihan Pekerja: Tinjauan Ke Atas Firma Terpilih Di Sektor Perkilangan, International Journal of Management Studies, 14 (2), 143-162.

SUHAKAM. (Human Rights Commission of Malaysia) (2012). Bantuan Ibu / Bapa Tunggal. Kuala Lumpur: Maziza Sdn Bhd.

UN, United Nation Development Programme. (2007). Towards a National action plan to empower single mothers. Kuala Lumpur.

Waring, M. K., \& Meyer, D. R. (2020). Welfare, work, and single mothers: The Great Recession and income packaging strategies. Children and Youth Services Review 108, 1-10.

Widan, R. J., \& Greeff, A. P. (2019). Aspects of Social Support Associated with Adaptation in Middle-Class, Single-Mother Families. The American Journal of Family Therapy, 47:3, 148-164.

Zakaria, M., Akhir, M. N., Omar, F. I. (2018). Kesejahteraan Psikologi Ibu Tunggal: Cabaran Sebagai Ibu Tunggal Dan Tekanan Hidup. e-Prosiding Persidangan Antarabangsa Sains Sosial dan Kemanusiaan 2018 (PASAK3 2018), 23-24 April 2018. Kolej Universiti Islam Antarabangsa Selangor, 579-589.

Zhao, X., \& Basnyat, I. (2018). Online social support for "Danqin Mama": A case study of parenting discussion forum for unwed single mothers in China. Computers in Human Behavior 80, 12-21. 